\title{
Phytoprotection
}

\section{Research Challenges and Needs for Safe Use of Arthropods : Introduction}

\section{Bernard J.R. Philogène}

Volume 79, numéro 4, 1998

OECD Workshop - Sustainable Pest Management, Safe Utilization of New Organisms in Biological Control. Montréal, Québec, Canada. September 27-30, 1998.

Atelier de l'OCDE - Gestion durable des ennemis des cultures, Utilisation sécuritaire de nouveaux organismes de lutte biologique. Montréal, Québec, Canada. 27-30 Septembre 1998.

URI : https://id.erudit.org/iderudit/706162ar

DOI : https://doi.org/10.7202/706162ar

Aller au sommaire du numéro

Éditeur(s)

Société de protection des plantes du Québec (SPPQ)l

ISSN

0031-9511 (imprimé)

1710-1603 (numérique)

Découvrir la revue

Citer cet article

Philogène, B. J. (1998). Research Challenges and Needs for Safe Use of Arthropods : Introduction. Phytoprotection, 79(4), 81-83.

https://doi.org/10.7202/706162ar d'utilisation que vous pouvez consulter en ligne. 


\title{
Research Challenges and Needs for Safe Use of Arthropods: Introduction
}

\author{
Bernard J.R. Philogène \\ Department of Biology, University of Ottawa, Ottawa, Canada K1N 6N5
}

"Killer ladybug threatens ecosystem". This was the headline in the Ottawa Citizen on July 20, 1998. The story behind the headline is a perfect example of what can happen as a result of the introduction of two beneficial insects from Asia to North America, in 1955. It is also indicative of how the popular press interprets scientific facts.

Two Coccinellidae - the seven-spotted ladybug (Coccinella septempunctata), and the nineteen-spotted ladybug (Harmonia axiridis, also known as the Asian multicolored ladybug) - have been reported to be gradually displacing some of their North American counterparts, so much so that the Canadian Nature Federation has embarked on a ladybug alert to collect as much information as possible on currently occurring ladybugs. The nine-spotted ladybug, Coccinella novemnotata, seems to be particularly threatened by $C$. septempunctata which was mass-released for control of the Russian wheat aphid. More than 170 species of lady beetles have been brought from overseas to North America as part of ongoing biocontrol programs. Has this love affair with lady beetles really led to a new form of biological crisis?

\section{A QUESTION OF RISK}

If we take what precedes as representative of the challenges that lie ahead for IPM specialists eager to favour biological control agents, we should really consider the risks associated with the use of entomophagous arthropods - and, for that matter, with the use of weed-controlling phytophagous arthropods. Simply defined, a risk is the probability that an adverse effect of some kind will occur. It is the probability of occurrence multiplied by the potential consequences of such occurrence, while risk assessment is the process of determining if or how such harm could be caused to non-target organisms, should a biological control agent start to utilize it.

As pointed out by Coats (1994), (i) perceived risks are not always consistent with actual risks, and (ii) the challenge of risk assessment is to identify the significant versus the trivial risks and then to address the most important and the most reducible.

It is both disturbing and challenging that, a hundred years after the spectacular introduction of the Australian vedalia beetle to control the cottony cushion scale in California, we should be questioning the advisability of using biological control agents - even though warnings were issued right from the start - and this at a time when sustainable development is the order of the day, reduced synthetic pesticide use has become common practice (from 1988 to 1993 chemical companies voluntarily dropped the registration of 28 actuve ingredients and 5000 pesticide products $\mathrm{n}$ the US alone), and increasing population pressure calls for more and better food production. Let us not forget that 40000 human beings die each day in developing countries as a result of food production deficiencies. 
The debate on risky biological control is already 15 years old and is illustrated by the number of articles that have specifically appeared on the subject (e.g. Howarth 1991, Onstad and McManus 1996, Simberloff and Stiling 1996). It seems to center primarily on the question of extinctions of non-target species, which is of primary concern in a context of preservation of biodiversity and sustainable development. Yet, recent contributions on what lies ahead for IPM ignore the risks that may be associated with biocontrol, regarding it as "very specific, nonpolluting, and safe".(Metcalf 1996). Indicative of the confidence of the promoters of biological control is the way in which some authors minimize environmental risk: "Environmental risk is correlated with the degree of host or target specificity of the introduced agent; so long as target-specific species are introduced, there should be little or no adverse environmental impact." (Ehler 1990).

When one considers the sheer number of biological control attempts during this century alone, one should actually be surprised that there have not been more documented problematic adverse consequences. But as some authors have well articulated, absence of evidence of negative environmental impacts is not evidence of absence of these impacts, or evidence that a species is not problematic elsewhere is not proof that it will not cause damage, or again that a few extinctions can confidently be assigned to a biological control agent, far from being grounds for comfort, should be cause for alarm. Should not the fact that, according to the Internet site of Base de dados tropical, Who's who in risk assessment of biological control agents, there are currently over 300 scientists working in this area, be quite revealing?

\section{APPROPRIATE SAFEGUARDS}

It is probably appropriate, at this time to mention the circumstances under which biological control work best: habitat type, pest feeding niche, voltinism, mobility of the entomophage, etc. For biological control agents to be effective there must be some specific attributes such as fitness and adaptability, high search capacity, host specificity, good competitive ability, etc.. Have all these aspects been properly researched? Has the entomophage's strategy for survival been adequately investigated from a physiological, an ecological and an evolutionary perspective?

These questions may appear to be obvious, but they take more significance when one considers the recent practice of ad-hoc biological control projects, if not mail-order biological control operations (there are currently more than 50 commercial insectaries across the United States selling predatory arthropods and parasitoids). Pest control often requires rapid intervention which does not usually agree with a sound biological control approach. Because pestmanagement specialists are primarily concerned with preventing or containing damage to crops, with increased yield, and with cost reductions, they do not necessarily envisage the ways in which biocontrol agents may affect the environment on a long term basis, i.e. beyond the parameters of pest control, and therefore the cascading ecological impacts. As underlined by Schmitz and Simberloff (1997) and others some biological control agents may attack nontarget organisms while only a third of introduced insects effectively control the targets, thus giving rise to what may be regarded as an insidious form of biological pollution.

Because biocontrol has been regarded as the "green alternative to chemical control" a certain dose of laisser-faire has permeated the regulatory system, thus opening the door to more hazardous introductions and unwanted consequences. In the words of Simberloff and Stiling (1996) biological control should be subjected to the same rigorous cost-benefit analysis and not automatically accorded the mantle of the environmentally friendly alternative. 


\section{MANAGING THE ECOSYSTEM OR THE PEST?}

Much attention has been given to the reasons why released entomophages were deemed to fail, but not much consideration has been given to environmental risks. The combination of the new biodiversity context and the threat to non-target species by entomophagous arthropods brings forth the information gaps which are a direct result of the way in which the science of biology has evolved.

We have moved from the systematic/ naturalist era to the reductionist/expansionist period and we are currently in an applied ecology context. In the systematic/naturalist era we described everything. We continue to look on organisms, but the attention of a majority of biologists has been diverted to the reductionist/expansionist period. Having discovered and described so many organisms, biologists then looked both inward and outward. Inward they examined organs, cells, organelles, molecules, etc pushing the boundaries further and further. The outcome has been the emergence of an enormous cohort of molecular biologists and biotechnologists who think that the future of mankind rests on their ongoing discoveries. Outward, biologists have studied populations, communities and ecosystems, modeling them with the help oh mathematics.

The current reality, however, is that the planet is paying the price for the consequences of human intrusion. Our incapacity to preserve ecosystem integrity and to capitalize on the benefits accruing from the reductionist/expansionist period is a direct result of the dismantling of our capacity to produce individuals capable of taking a more global and integrated approach to ecosystem management. For the proper use of biological control agents is a problem of ecosystem management before one of pest management. To paraphrase Reeves (1998) to remain sustainable biological control must continually be supported with new knowledge, new practices, new technology. But this approach must not ignore some fundamental principles and the capacity to implement these principles. Effective biological control requires real expertise of the systematics of the pest, the entomophages and the non-target species (hosts/prey) (Howarth 1991).

There is a real need to understand more about the adaptation of entomophages to all components of natural and modified (agriculture/forestry) ecosystems, with special emphasis on the study of the biology of many non-target species. This calls for a greater input, in a truly multidisciplinary approach, of specialists in biosystematics, evolutionary biology, arthropod physiology and behaviour, ecology, and IPM.

Considering that the amount of money spent on biocontrol endeavours is hardly $1 \%$ of the multi-billion dollars expenditure for the entire insect control market, substantial investments are required to make biological control (1) a more common practice and (2) a really safe method of pest management.

\section{KEY REFERENCES}

Ehler, L.E. 1990. Revitalizing biological control. Issues in Science and Technology, 7: 91-96.

Howarth, F.G. 1991. Environmental impacts of classical biological control. Annu. Rev. Entomol. 36: 485-509.

Metcalf, R.L. 1996. Applied entomology in the twenty-first century. Needs and prospects. Amer. Entomol. 42: 216-227.

Onstad, D.W. and M.L. McManus. 1996. Risks of host range expansion by parasites of insects. BioSccience, 46: 430-435.

Reeves,T.G. 1998. Sustainable Intensification of Agriculture. Mexico, D.F.:CIMMYT. 36p.

Schmitz, D.C. and D. Simberloff. 1997. Biological invasions: a growing threat. Issues in Science and Technology, 13: 33-40.

Simberloff, D. and P. Stiling. 1996. How risky is biological control? Ecology, 77: 19651974. 